\title{
Student governments in Chinese higher education: reflection on college students' and student cadres' political trust
}

\author{
Wei Huang ${ }^{1} \cdot$ Panpan Yao ${ }^{1} \cdot$ Fan $^{\mathrm{Li}^{2}}{ }^{\mathrm{D}} \cdot \mathrm{Xiaowei}_{\mathrm{Liao}}{ }^{1}$
}

Accepted: 17 May 2021 / Published online: 22 May 2021

(C) The Author(s) 2021

\begin{abstract}
This paper documents the structure and operations of student governments in contemporary Chinese higher education and their effect on college students' political trust and party membership. We first investigate the structure and power distribution within student governments in Chinese universities, specifically focusing on the autonomy of student governments and the degree to which they represent students. Second, using a large sample of college students, we examine how participating in student government affects their political trust and party membership. Our results show that student government in Chinese higher education possesses a complex, hierarchical matrix structure with two main parallel systems - the student union and the Chinese Communist Party system. We found that power distribution within student governments is rather uneven, and student organisations that are affiliated with the Chinese Communist Party have an unequal share of power. In addition, we found that students' cadre experience is highly appreciated in student cadre elections, and being a student cadre significantly affects their political trust and party membership during college.
\end{abstract}

Keywords Higher education governance - Student government · Student cadres · Political trust . China

Fan Li

fan.li@wur.nl

Wei Huang

huangwei197514@163.com

Panpan Yao

panpanyao199147@126.com

Xiaowei Liao

liaoxw2011@163.com

Extended author information available on the last page of the article 


\section{Introduction}

High-quality higher education (HE) depends on both investments in financial and human resources (Johnstone, 2003) and good governance (Rytmeister, 2009; Vidovich \& Currie, 2011). The existing literature on governance in HE focuses primarily on external factors, including public financing (Hirsch, 2001), quality assessment (Currie et al., 2003), and the massification and commodification of HE (Christopher, 2012; Marginson \& Considine, 2000). However, a significant portion of the literature focuses on internal HE governance, namely students' involvement in HE governance (Boland, 2005; Menon, 2005; Luesher-Mamashela, 2013).

Although it takes different forms across countries and regions (Akomolafe \& Ibijola, 2011; Kuruuzum et al., 2005), student involvement appears to exert a significant influence on HE governance. Students' involvement in curricula design and teacher evaluation can yield significant improvements in HE quality (McFarland \& Starmanns, 2009; Obondo, 2000). Participating in student volunteer organisations can also greatly improve the quality of campus life and socialisation (Kuh \& Lund, 1994). Generally, students' involvement in university governance has a significant positive effect on their development.

Despite the extensive literature on students' involvement in HE governance, China-specific research is comparatively scarce. This is worth exploring for two reasons. First, Chinese HE accounts for a substantial share of global HE (Altbach, 2009; Hornsby \& Osman, 2014; Mok, 2016), leading to the massive expansion of student enrolment, spurring the globalisation of $\mathrm{HE}$ and profoundly changing contemporary HE governance in China (Dill, 2007; Giannakis \& Bullivant, 2016; Neubauer \& Gomes, 2017; Ngok, 2008; Yang, 2005). Second, the Chinese government has been actively reforming HE; in 2017, it unveiled the national 'Double FirstClass University Plan', its most ambitious attempt yet to improve HE quality (Ministry of Education [MoE], 2017). The Chinese government has also sought substantial financial investment (Grove, 2017; Liu et al., 2019) alongside policy reforms to improve the efficiency and effectiveness of HE governance (Peters \& Besley, 2018). Considering the recent pace of China's socio-economic development and the potential impacts of its HE on both global HE and the global labour market, understanding internal HE governance in China might shed some light on the future of HE governance and HE development in China and globally.

This paper seeks to examine a particular form of students' involvement in the country's HE governance - student government (SG). First, the perceived legitimacy of national political systems has profoundly influenced student politics both in China and the West (Altbach, 1984). In China, HE governance is significantly influenced by the Chinese Communist Party (CCP; Huang, 2006). Second, since the economic reform in the 1980s and the later HE reforms in 1999, HE governance in China has been oscillating between centralisation and decentralisation (Wang, 2010). SGs undoubtedly play a central role in reconciliating party-centralised leadership and decentralised HE autonomy. Thus, to understand the internal governance of contemporary Chinese HE, three primary questions need to be addressed. First, how is SG structured, and how does it operate to reconcile the demand for student representation, political autonomy, and other stakeholders' needs? Second, what kind of students are selected as student cadres? Finally, how does being a student cadre affect students' political choices and beliefs? These three questions are closely interlinked. On the one hand, the structure of SGs and its internal operation significantly affect its criteria in determining who should be student cadres and its generating procedures. Such an internal mechanism should not only be observed in qualitative observations, but also should be measured through quantitative 
statistics; on the other hand, how student cadres are generated and how being a student cadre affects their political choices and beliefs could further verify or reinforce the qualitative observations, which are essential in making further inferences about SGs in Chinese HE governance.

Thus, to answer these questions, our paper examines these three elements through two major sections. First, we use qualitative case studies to analyse SG in Chinese universities by examining (a) the structural distribution of power within SGs and (b) student representation by investigating and detailing how student cadres are elected. Second, we use large-scale quantitative data to examine what characteristics associated with being student cadres, and how being a student cadre is associated with their political trust and party memberships.

\section{Literature review}

Although SG in HE can be traced back to the 1700s (May, 2010), most studies on SG and its influences on HE governance are relatively recent (Houwing \& Kristjanson, 1975; Jones \& Skolnik, 1997; Klemenčič, 2012; Klemenčič et al., 2015). Two strands of studies are particularly relevant. The first are those that focus on SGs' organisational characteristics (volunteer run or party affiliated) and investigate how SGs' political opportunities and resources affect their organisational structure, cadre selection, and decision-making processes (Day, 2012; Parejo \& Lorente, 2012; Stensaker \& Michelsen, 2012). These scholars often study power distribution in HE governance by assessing the autonomy of SGs and student representation within the SGs (Jessup-Anger, 2020; Klemenčič, 2014). For instance, Luescher (2013) discussed the advantages of student representation in HE governance and provided several paradigms through which researchers can examine this phenomenon. Later, Luescher \& Klemenčič, 2016) studied the representation of student organisations in several African countries and concluded that political parties often have a significant influence on HE students' politics, with ruling political parties exhibiting the most influence. These studies helped us form an analytical framework through which to investigate student governance in Chinese HE.

The second strand of literature addresses how students develop leadership qualities through their involvement in SG and how being a student cadre affects different student outcomes (Beaman et al., 2012; Bertrand \& Schoar, 2003; Chattopadhyay \& Duflo, 2004; Deng et al., 2020; Jones \& Olken, 2005; Malmendier \& Tate, 2005). These studies suggest that student cadres have a significant effect on organisational performance because the type of students who become student cadres affects the operations of SGs. Other studies examine how the experiences of being a student cadre affects the development of leadership skills by, for instance, detailing the influence of different psychological factors (e.g. self-efficacy, grit, and adaptability) on students' leadership efficacy (Anderson \& Galinsky, 2006; Galinsky et al., 2003; Galinsky et al., 2006). However, being a student cadre not only helps students develop their managerial skills but also partially determines their social competencies and their social and political participation (Downey et al., 1984). For example, Pascarella and Terenzini (1991) and Kuh and Lund (1994) show that being a student cadre significantly improves students' social skill development (such as teamwork, critical thinking) and their political participation after graduation.

Our study contributes to the literature in two ways. First, it is among the first (if not the first) to study SGs in the context of HE governance in China. By assessing the autonomy and degree of student representation in SGs, this study enables a comprehensive understanding of the 
structure and operation of SGs in contemporary Chinese universities. It not only enriches the literature about SGs in developing countries but also provides the basis for scholars to examine subsequent changes in contemporary Chinese SGs. Second, this is among the few empirical studies to examine the relationship qualitatively and quantitatively between being a student cadre and their political trust and party membership. By facilitating an understanding of SGs in contemporary Chinese HE and its relationship with college students' political trust and party membership, we hope to provide a basis for policies to improve HE governance in China.

\section{Qualitative reflections on SGs in Chinese HE}

To analyse the structures of Chinese SGs and assess its day-to-day operations, a series of indepth, semi-structured interviews were conducted between September 2018 and July 2019. We interviewed 50 staff, student cadres, and students from seven universities in Hunan province. Interviewees were distributed among top-, median-, and bottom-tier universities as per MoE rankings. As all top- and median-tier universities are public universities, our focus is on public universities. Although there were some minor differences in SGs, the essential institutional arrangement at all seven universities was astonishingly unanimous. This makes us confident that we can extend our qualitative findings to other Chinese HE institutes. Furthermore, our interviewees repeatedly confirmed our findings when relaying their personal experiences. We present the qualitative findings in two steps. First, we show the structure of SGs in Chinese HE and analyse power distribution and autonomy. Second, we examine how student cadres are elected and analyse the factors that drive governments' election protocols through the lens of student representation.

\section{Structure and power distribution within SGs}

The concept of SGs in Chinese HE is rather vague. The use of the word 'governments' is not strictly appropriate because of the absence of the power to enforce laws (MoE, 2016). For instance, according to one of our interviewees, who works in university administration [HN1101-05]:

It is inappropriate to use the term government (in Chinese, 政府) to name the university associates or organisations. None of them are government, and [they] do not inherit any government characteristics.

However, we use the term 'SG' to emphasise the quasi-governmental characteristics and operations of these student associations and organisations. Broadly, SGs in Chinese universities consist of two main parallel systems: student union systems (学生会) and CCP partyaffiliated systems (党/共青团委会). Figure 1 describes the structure of SGs with a three-level, top-down hierarchy.

\section{Dual nature of SGs in Chinese HE}

Student unions are the main channel through which student organisations handle studentrelated affairs. They officially represent students and facilitate students' involvement in making joint decisions with other stakeholders (university administrative boards, the CCP, faculty, etc.). The structures of student unions are typically decentralised. At the university 


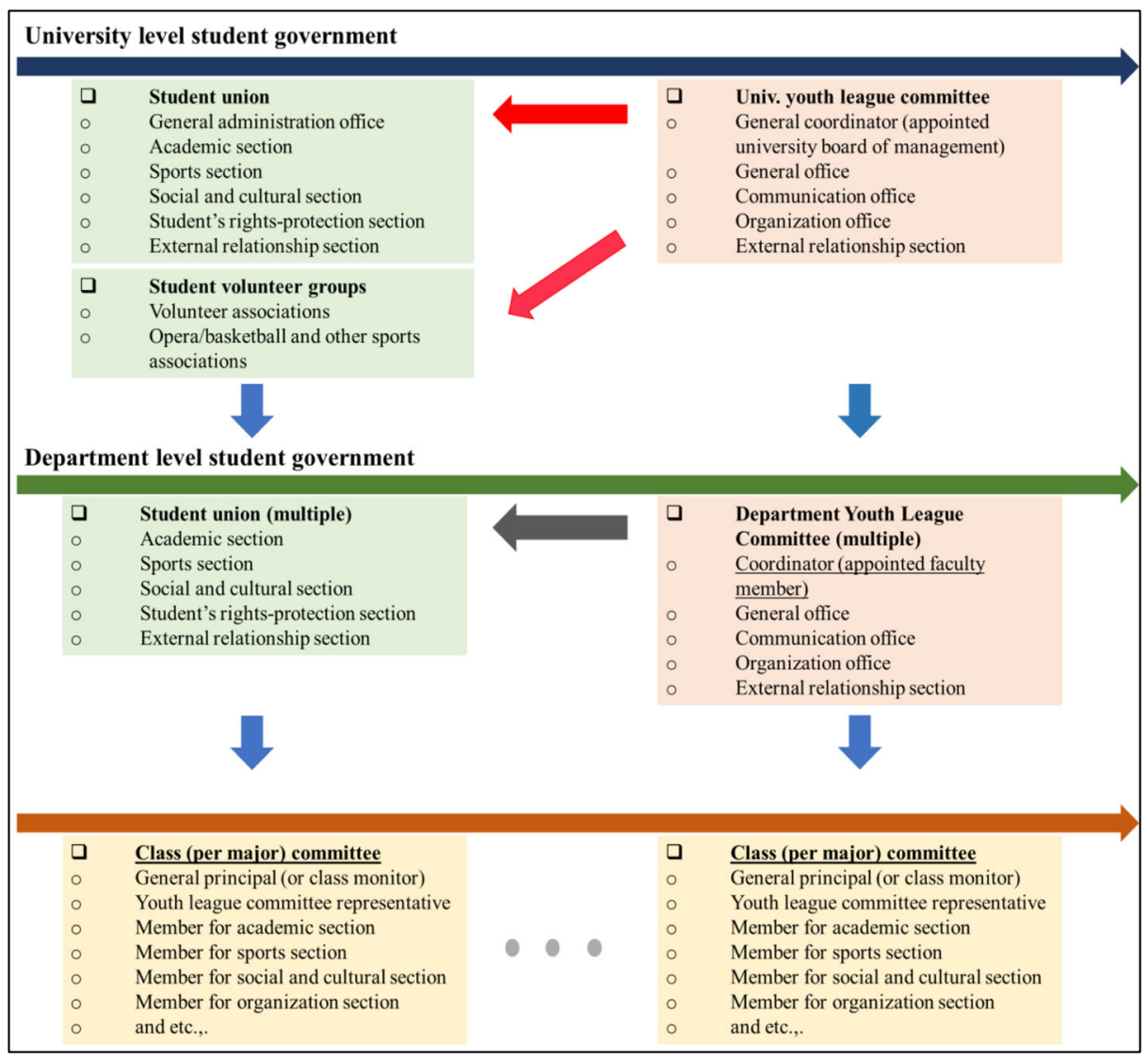

Fig. 1 The structure of student government in China's higher education institutes. Data source: authors' survey

level, student unions consist of multiple offices or ministries and are responsible for attending to student affairs involving external stakeholders or multiple university departments. At the department level, each university department organises its student union independently. ${ }^{1}$ Department-level student unions are structured similar to university-level student unions and operate only within their own department across different levels of student seniority. At the class level, students form a large number of 'class committees' (班委会) that take care of student-related affairs within a given class or year.

The CCP has a strong presence within SGs. Unlike the student union system, the CCPaffiliated system has a top-down and deeply hierarchical structure. It consists of two main institutions - Communist Youth League Committees (CYLC, 共青团委会) and universities' Communist Party Committees (CPC, 党委会). Whereas CYLCs are a primarily studentinvolved institution, CPCs are linked directly to university governance. Each university has a CPC, which has a strict, top-down hierarchy and comprises mostly university staff. CYLCs operate under the direct supervision and administration of CPCs. College students can apply to be CPC members via their local CYLC, but few successfully join CPCs before they graduate.

\footnotetext{
1 'Department' is used to indicate all different names in university administration, such as school, faculty, and college. 'Major' is used to indicate the smallest unit of the university management.
} 
Although CYLC members are primarily students, CYLC chairs at both the university and department level are always administrative staff appointed by the university's CPC. In short, this strongly top-down institutional arrangement ensures that CPCs have strong and centralised control over CYLCs.

\section{Autonomy of SGs in Chinese HE}

The vertical structure of CYLCs and CPCs ensures that the CCP-affiliated systems have a high degree of centralisation. In addition, it ensures that power is distributed unevenly between CYLCs/CPCs and student unions, potentially undermining SGs' autonomy. However, this does not indicate that student unions have zero autonomy. First, student unions of all levels adopt a rather decentralised approach to their day-to-day operations. University- and department-level student unions do not supervise or coordinate lower-level student unions' or class committees' operations directly, and higher-level student unions seldom intervene in the affairs of lower-level student unions. Class committees can organise their own public events, set their own budgets from students' contributions, and negotiate with university administrators and faculty members on behalf of their members. For instance, an interviewee (a department student union cadre) [HN-1103-02] explained:

Our department student union has our own agenda and financial budget. The university student union does not intervene in our programme or planning. We do sometimes collectively organise some student event with the university student union, but mostly we make decisions by and for ourselves.

Second, although CYLCs supervise their corresponding student unions and class committees, this supervision focuses primarily on CCP-related activities, such as selecting candidates to join the CPC and organising activities. Officially, CYLCs cannot be involved in student unions' non-CCP-related decision-making; however, they do play a monitoring role to ensure the transparency of decision-making processes and avoid conflicts of interest. Our interviewees indicated that student unions have some measure of autonomy, while the strong informal presence of CYLCs and CPCs affects student unions' decision-making and operations. Notably, because the public's and the CCP's interests can be defined broadly and subjectively, CYLCs play an important role in student union activities. For instance, a university student union cadre [HN-1103-08] said:

Of course, as the university student union we have our own scope of duties and responsibilities. However, we are also under the university CCP lead; communicating with the university CYCLs and the CCP is important to make sure that our activities are also supported by the university administrative offices. I personally do not think there would be any conflicts between the university student union and the CYLCs or the CCP; however, this collaborative relationship is based on good communication.

The extent to which these bodies' informal presence affects the operations of student unions depends on the issue at hand and how these bodies define the public's and CCP's interests. In summary, we found that although there is a degree of decentralisation within student unions, the presence of CYLCs and CPCs means that in practice, SGs can be rather centralised, and party-affiliated bodies have the lion's share of formal and informal power. Such an institutional arrangement implies that there might be a significant tendency among student cadres to attach the party system in reality. For instance, student cadres might show a 
significant higher political trust, and actively join the CPCs than non-cadre students during their college study.

\section{Elections and student representation}

The operation of SG highly depends on student cadres, who represent students and process student-related affairs among different entities. To examine how student cadres are selected and their representativeness, we first elaborate on the election process in both the student union and party-affiliated systems and then compare their election processes from the perspective of student representation.

\section{Election or selection?}

There are strict protocols for student cadre elections among different SG entities. Here, we outline their defining characteristics for student unions and party-affiliated bodies alike.

The processes governing student union elections appear to be elective in nature but much more selective in practice. As shown in Fig. 2, the chair and vice-chairs of university- and department-level student unions are mostly third-year bachelor's students, and the 'ministers' of each office within student unions are mostly second-year bachelor's students. First-year students who wish to join student unions are subjected to evaluations by incumbent representatives at the beginning of each academic year. These evaluations assess candidates' abilities based on the requirements of each specific office. Candidates are required to give a public speech about their qualifications. Incumbent student cadres make final decisions about who will join the student union. Selected first-year student cadres mostly help senior cadres organise student-related affairs and play a limited role in decision-making. After the school year is over, first-year cadres compete for promotions to 'minister' roles (of which two are available per office) and second-year cadres compete for the positions of chair and vice-chairs. These competitions are governed by the same processes, and winners are selected by the incumbent chair, vice-chair, and ministers. The corresponding CYLC supervises the election process but is not involved in final decisions. As an interviewee from the department CYLC [HN-1106-02] told us:

We are not involved in student cadre election in either the department student union or class committees. There are senior student cadres making their evaluation in the [department] student union. Once they have selected (voted) their candidates, we at CYLC have to confirm the election procedure and the results. That's all. We are also not involved in class committee election. Each class has their own election.

However, student cadre elections within CYLCs are rather limited in scope. As with student unions, elections at CYLCs are like selection processes. First, all candidates must be official members of the CYLC, and students who apply to become CYLC cadres are subject to evaluation by their seniors. ${ }^{2}$ Second, the criteria for becoming a CYLC student cadre are quite blurry. Senior CYLC cadres weigh candidates' political beliefs and opinions rather heavily, even though these elements are subjective. This renders senior CYLC cadres' subjective

\footnotetext{
${ }^{2}$ Over $95 \%$ of surveyed students have been CYLC members since high school. Many noted that students are often encouraged to join CCP-affiliated student organisations in primary and middle school.
} 


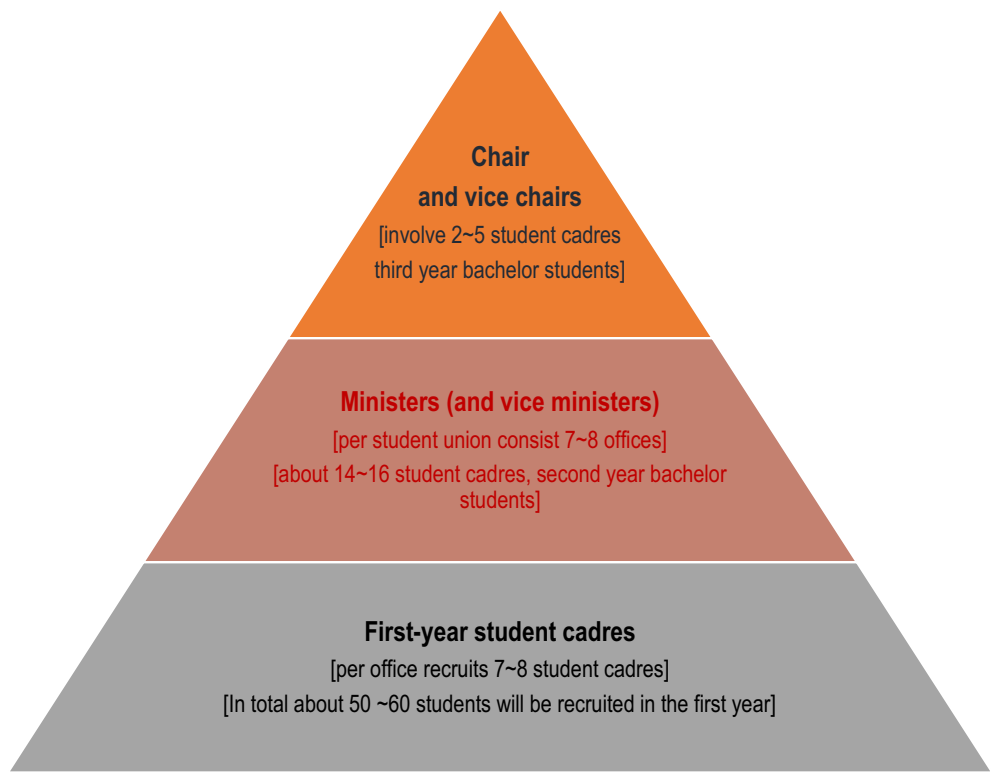

Fig. 2 The structure of the student union and the number of student cadres. Note: The hierarchy of the student unions, including the university student union and department student unions

opinions a crucial factor in the selection process. Third, public demands for transparency have limited the arbitrariness of senior cadres' judgements to some extent, alternatively leading to an increasing amount of importance being placed on academic performance, even though being a CYLC student cadre is not an academic or results-driven appointment. For instance, the interviewee above [HN-1106-02] explained:

In fact, academic performance is the most and only convincing criterion in electing a qualified student cadre. Of course, it is not necessary that candidates have all tests with the best scores; but the candidates cannot have poor academic performance, because only exam scores are open, transparent, and objective. So, if someone wants to be a student cadre, she/he first has to make sure to have good academic performance.

Furthermore, the CYLC chair is a member of the university's administrative staff, appointed by the corresponding CPC. In fact, the chair is not selected through an election process. Thus, the CPC exerts a strong influence on CYLC elections and operations.

Class committees, the lowest level of student government units, manage almost $90 \%$ of student-related affairs. Unlike university- and department-level student unions or the CYLC elections, which are limited in scope and strongly influenced by the CPC, class committee membership is determined by a class-wide vote. A public campaign and election are organised at the beginning of each school year. Candidates are required to give a public speech. The election itself is supervised by the corresponding CYLC and decided by a vote. Winning candidates must receive at least twothirds of the total vote. CYLCs exert a small amount of influence on these elections; for instance, winning candidates must be formally approved by the relevant department's CYLC to ensure that they represent the interests of a given class and the department administrators alike. 


\section{Elections and student representation}

We now examine representation among different election processes. Although the election process does not guarantee student involvement in decision-making, it offers students a basic channel to participate in university governance. We noticed that class committee elections have higher levels of student representation than student union and CYLC elections. First, all students participating in class committee elections share an equal and non-exclusive right to vote and campaign. This procedure is far more open than student union and CYLC elections, which are decided by incumbent student cadres. For example, a field interviewee [HN-110907] said:

I had never participated in any election or voting of the department student cadres. I do not think I can join given that I am not even affiliated to the class committee. I guess it is only open to students who have been in the department CYLC or student union. I did not join any of these organisations. But voting for the class committee is obligatory. All of us have to participate in the election at the beginning of the academic year.

Second, students who are elected to the class committee receive a procedural guarantee of wide support from their fellow students, unlike their counterparts in student unions and CYLCs. When class committee electoral candidates do not receive two-thirds of the overall vote, there are additional rounds of campaigning and voting. In contrast, senior and incumbent students dominate the decision-making processes in student union and CYLC elections, and the results of both elections are significantly affected by CPC members. In short, there is almost no institutional guarantee that student unions and CYLCs represent students and are supported by the majority of the student body.

Third, the results of class committee elections are rather definitive and subject to minimal influence from other stakeholders, especially CYLCs. Although CYLCs monitor the class committee elections, the results cannot be overturned unless two-thirds of students demand another election. That election results are so definitive which demonstrate that class-level student governance is strong and decentralised. In contrast, the influence of CYLCs in student union elections and the fact that CYLC elections are directly supervised by CPCs demonstrate that these bodies' elections could be more centralised and less representative as the class committee election. Although our interviewees stated that they rarely observed conflicts between CYLCs and elected student union cadres, it is possible for the CYLC to reject an elected student cadre. In short, there is a significant lack of student representation in universityand department-level student unions and CYLCs. In this case, students' interests might be systematically neglected, further undermining the representativeness of SGs in HE.

\section{Quantitative study}

The qualitative investigation above serves as an illustration of contemporary SG in Chinese HE; however, to empirically test these observations, some quantitative methods are needed. Thus, to quantitatively examine the day-to-day operations of SGs in Chinese HE, and given the analytical framework developed above, we focused on two empirical questions. First, who are student cadres in Chinese universities? Second, how is being a student cadre associated with political trust and party membership? To answer these questions, we conducted largescale surveys in 2016 and 2018. Our respondents came from seven universities in Hunan 
province, one of China's most significant provinces for HE (Hunan Department of Education, 2017).

\section{Data}

The first-round data collection was implemented in October 2016, immediately after incoming students started their first year. To ensure representativeness, we randomly sampled seven universities and $10 \%$ of first-year students from each of the universities' departments. A total of 2557 first-year students participated in the survey. This first survey sought four distinct types of information. First, we collected detailed data on students' demographics (e.g., age, gender, academic performance, urban/rural residence) and parents' and family's socioeconomic background. Second, we asked if the student currently served as a student cadre (and if yes, which type) and whether she/he had been a student cadre in high school (this previous experience helps us capture some significant but unobservable characteristics, such as social and other non-cognitive skills). Third, we asked about post-graduation plans, expected salary, and the expected likelihood of finding a major-matched job. Fourth, the survey assessed personality traits - including leadership efficacy, study strategy, academic self-efficacy, grit, and adaptability - using scales that are presented in our online supplementary documents. These psychological scales have been used in previous studies to examine how personality traits affect college students' outcomes (Elliot, 1999; Elliot \& Church, 1997; Midgley et al., 2000).

The follow-up survey was conducted in September 2018. All 2557 students participated the follow-up survey. This survey confirmed participants' cadre status and whether or not they had joined the CCP over the previous two years. Further, we measured students' political trust to disentangle the relationship between being a student cadre and one's political choices. To assess their political trust, we adopted a well-developed scale (Fang \& Wang, 2018) consisting of eight questions relating to political institutions, government, and the current government's politicians. Table 1 displays the scale in detail, and in Table 2, we present the basic descriptive statistics.

Table 1 Measurement of students' political trust

\begin{tabular}{ll}
\hline Scale & Items \\
\hline Student political trust scale & $\begin{array}{l}\text { 1. Have a great confidence in China's development path, governance and its } \\
\text { institutions. }\end{array}$ \\
$\begin{array}{l}\text { Measured with a 5-point } \\
\text { Likert scale }\end{array}$ & $\begin{array}{l}\text { 2. Trust the current political institutions. } \\
\text { 3. Do you believe that the central government always thinks of the people and do } \\
\text { good things for the people? }\end{array}$ \\
$\begin{array}{ll}\text { 4. Do you believe that the local governments in your hometown always do good } \\
\text { things for the people? }\end{array}$ \\
$\begin{array}{l}\text { 5. How do you recognise (or acknowledge) the current ministry of education and } \\
\text { the ministry of finance? } \\
\text { 6. Do you recognise the public security institutes, the court and the people } \\
\text { liberation army (PLA)? } \\
\text { 7. Do you trust the party leaders and the state leaders? } \\
\text { 8. Do you trust the government staff in your hometown? }\end{array}$
\end{tabular}

Note: The scale was developed by Fang, W., and Wang, M. (2018). Empirical research of factors influencing college students' political trust: Analysis of university-related factors and the current situation, Journal of Shanghai Jiaotong University (Philosophy and Social Sciences), 26(1), 53-62 
Table 2 Summary of all the variables

\begin{tabular}{|c|c|c|c|c|c|c|}
\hline & Variable & mean & std. & $\min$ & $\max$ & $\mathrm{VIF} \dagger$ \\
\hline & (1) & (2) & (3) & (4) & $(5)$ & (6) \\
\hline \multicolumn{7}{|l|}{ Measured students' outcomes (surveyed in 2018) } \\
\hline 1. Students' political trust & Continuous & 11.88 & 1.80 & 2.77 & 13.86 & \\
\hline 2. Is a CCP member, $1=$ yes & Dummy & 0.05 & 0.22 & 0 & 1 & \\
\hline \multicolumn{7}{|l|}{ Core independent variables } \\
\hline $\begin{array}{l}\text { 3. Student cadre at univ. or department entities for } \underline{\mathbf{O N E}} \\
\text { year, } 1=\text { yes }\end{array}$ & Dummy & 0.26 & 0.44 & 0 & 1 & 1.06 \\
\hline $\begin{array}{l}\text { 4. Student cadre at univ. or department entities for TWO } \\
\text { years, } 1=\text { yes }\end{array}$ & Dummy & 0.05 & 0.23 & 0 & 1 & 1.06 \\
\hline 5. Student cadre at class committee for $\mathbf{O N E}$ year, $1=$ yes & Dummy & 0.30 & 0.46 & 0 & 1 & 1.18 \\
\hline 6. Student cadre at class committee for $\overline{\text { TWO years, }} 1=$ yes & Dummy & 0.18 & 0.38 & 0 & 1 & 1.18 \\
\hline 7. High school student cadre, $1=$ yes & Dummy & 0.72 & 0.45 & 0 & 1 & 1.10 \\
\hline \multicolumn{7}{|l|}{ Personality traits and future expectations (surveyed in 2016) } \\
\hline 8. Measured leadership skills & Continuous & 8.64 & 2.50 & 4 & 16 & 1.22 \\
\hline 9. Students' study strategy & Continuous & 14.42 & 3.10 & 3 & 27 & 1.21 \\
\hline 10. Measured student's self-efficacy & Continuous & 16.13 & 3.76 & 5 & 25 & 1.36 \\
\hline 11. Students' grit & Continuous & 23.33 & 3.31 & 8 & 40 & 1.12 \\
\hline 12. Student's adaptation to college study & Continuous & 45.09 & 7.29 & 12 & 60 & 1.21 \\
\hline 13. Plan to do a master after graduation, $1=$ yes & Dummy & 0.43 & 0.49 & 0 & 1 & 1.75 \\
\hline 14. Plan to work in the labou & Dummy & 0.34 & 0.47 & 0 & 1 & 1.67 \\
\hline $\mathrm{an} / \mathrm{month}$ & Continuous & 3.8 & 1.64 & 1 & 10 & 1.10 \\
\hline 16. Probability to find a major-matched job $(\%)$ & Continuous & 52.89 & 21.49 & 0 & 100 & 1.11 \\
\hline \multicolumn{7}{|l|}{ Students' individual characteristics (surveyed in 2016) } \\
\hline 17. Female student, $1=$ yes & Dummy & 0.52 & 0.49 & 0 & 1 & 1.17 \\
\hline 18. Stude & Continuous & 18.25 & 0.85 & 13 & 23 & 1.21 \\
\hline 19. Rural student, $1=$ yes & Dummy & 0.63 & 0.48 & 0 & 1 & 1.56 \\
\hline 20. Minority student, $1=$ yes & Dummy & 0.49 & 0.28 & 0 & 1 & 1.04 \\
\hline nember, $1=$ yes & Dum & 0. & 0.14 & 0 & 1 & 1.02 \\
\hline hother province, $1=y e s$ & Dummy & 0.40 & 0.49 & 0 & 1 & 1.17 \\
\hline 23. College entrance exam scores & Continuous & 473.64 & 74.73 & 197 & 681 & 1.16 \\
\hline \multicolumn{7}{|c|}{ Parents, family, and students' high school characteristics (surveyed in 2016) } \\
\hline 24. Father education, in years & Continuous & 10.38 & 3.23 & 0 & 19 & 1.86 \\
\hline 25. Mother education, in years & Continuous & 9.49 & 3.40 & 0 & 19 & 1.97 \\
\hline 26. Father is migrant worker, $1=$ yes & Dummy & 0.51 & 0.50 & 0 & 1 & 1.64 \\
\hline nigrant worker, $1=y e s$ & Dummy & 0.36 & 0.48 & 0 & 1 & 1.60 \\
\hline 28. Family size & Continuous & 4.16 & 1.19 & 2 & 8 & 1.58 \\
\hline 29. Single child family, $1=y e s$ & Dummy & 0.46 & 0.50 & 0 & 1 & 1.76 \\
\hline 30. Richest $33 \%$ family, $1=y e s$ & Dummy & 0.33 & 0.47 & 0 & 1 & 1.70 \\
\hline 31. Poorest $33 \%$ family, $1=$ yes & Dummy & 0.33 & 0.47 & 0 & 1 & 1.62 \\
\hline 32. Highest $33 \%$ in intellectual capital, $1=$ yes & Dummy & 0.33 & 0.47 & 0 & 1 & 1.67 \\
\hline 33. Lowest $33 \%$ in intellectual capital, $1=y e s$ & Dummy & 0.33 & 0.47 & 0 & 1 & 1.54 \\
\hline 34. Is a key model high school, $1=y e s$ & Dummy & 0.81 & 0.40 & 0 & 1 & 1.10 \\
\hline
\end{tabular}

Note: $\dagger$ To check if there is a strong multicollinearity issue, we examined the variance inflation factor (the VIF) to check how strong the correlations among the covariates we used. Overall, the VIF is rather low, and the mean VIF is only 1.36, much smaller than 2. Thus, we are less concern about the multicollinearity issue in our empirical analysis

Data source: author's survey

\section{Analytical approach}

\section{Factors associated with being a student cadre}

Given the richness of the data, to explore the factors associated with being a student cadre, we ran two empirical models. First, we examined which personal characteristics were associated with a first-year student being (s)elected as a cadre using the following probit model: 


$$
M_{i j, t=1}^{s t u-g o v}=\Phi\left(\alpha_{0}+\alpha_{1} C_{i j}^{h s}+\alpha_{2} A_{i j}^{c e e}+\alpha_{3} P_{i j}^{\prime}+\alpha_{4} S_{i j}^{\prime}+\alpha_{5} F_{i j}^{\prime}+\delta_{j}+\varepsilon_{i j}\right)
$$

where $M_{i j, t=1}^{s t u-g o v}$ is a dummy variable representing if student $i$ at university $j$ is a student cadre during their first school year. The explanatory factors included students' high school cadre experiences $\left[C_{i j}^{h s}\right]$, academic performance (measured by college entrance exam (CEE) scores, $\left.\left[A_{i j}^{c e e}\right]\right)$, personality traits $\left[P_{i j}^{\prime}\right]$, demographic characteristics $\left[S_{i j}^{\prime}\right]$, and family's socio-economic background $\left[F_{i j}^{\prime}\right]$. Previous studies have shown that these variables might be significantly correlated with being a student cadre (Deng et al., 2020; Komives \& Johnson, 2009; Lundin et al., 2019). Here, $\delta_{j}$ represents the university department fixed effect, and $\varepsilon_{i j}$ represents the clustered standard error term at the department level.

Based on the first model, we examined the factors associated with being (s)elected as a student cadre in their second school year. This model examined how first-year students' cadre experiences contributed to their (s)election in the second school year. It is important to disentangle the relationship between first- and second-year cadre (s)election for two reasons. First, competition within university- and department-level student organisations becomes fiercer because few positions are available and evaluation by senior cadres is a deciding factor. Second, after a year's experience, students (both voters and candidates) gain more knowledge about the positions and their requirements. Thus, first-year student cadre experience is crucial to winning promotions/elections. We ran a second probit to better define this advantage:

$$
M_{i j, t=2}^{s t u-g o v}=\Phi\left(\beta_{0}+\gamma_{1} M_{\mathrm{i} j, t=1}^{s t u-g o v}+\gamma_{2} A_{i j, t=1}^{G P A}+\beta_{1} C_{i j}^{h s}+\beta_{2} A_{i j}^{c e e}+\beta_{3} P_{i j}^{\prime}+\beta_{4} S_{i j}^{\prime}+\beta_{5} F_{i j}^{\prime}+\delta_{j}+\varepsilon_{i j}\right)
$$

where $M_{i j, t=2}^{\text {stu-gov }}$ represents if student $i$ at university $j$ is a student cadre during their second school year. We added a variable $M_{i j, t=1}^{\text {stu-gov }}$ (first-year student cadre status) to capture the advantage of being an incumbent. We also added students' first-year grade point average (GPA) $\left(A_{i j, t=1}^{G P A}\right)$ to control for the potential effects of academic performance. If certain student characteristics show outstanding significance in both models, we can be more confident in making inferences.

\section{Being a student cadre and studentsects of academic performances}

As the qualitative observations implied the CCP's dominant role in SGs, we expected a significant correlation between being a student cadre and political trust and party membership choices. To examine if such a correlation exists, while taking into account the changes in student cadre status over the past two years, we specified the following model:

$$
Y_{i j, t=2}^{\text {outcomes }}=\alpha_{0}+\alpha_{1} M_{i j}^{1}+\alpha_{2} M_{i j}^{2}+\alpha_{3} C_{i j}^{h s}+\alpha_{4} A_{i j}^{c e e}+\alpha_{5} P_{i j}^{\prime}+\alpha_{6} S_{i j}^{\prime}+\alpha_{7} F_{i j}^{\prime}+\delta_{j}+\varepsilon_{i j}
$$

where $Y_{i j t=2}^{\text {outcomes }}$ represents students' outcomes of interest. $M_{i j}^{1}$ is a binary variable, indicating if a student has been a cadre for at least one year; $M_{i j}^{2}$ indicates if a student has been a cadre for two academic years. All other control variables in model (3) are the same as in models (1) and (2). We further add the department dummies to eliminate influences at the department and university level. $\varepsilon_{i j}$ is the clustered robust standard error term at the department level. The coefficients $\alpha_{1}$ and $\alpha_{2}$ capture the relationship of being a student cadre and the measured student outcomes. 
The above regression analyses (with either ordinary least square or probit model) provide us with a good benchmark estimation. However, to reduce potential bias due to sample selfselection, and given that cadre experiences during the previous two years can be estimated as a multi-valued treatment (Cattaneo, 2010; Imbens, 2000), we further use the inverse probability weighted regression adjustment (IPW-RA) estimator to perform the robustness analysis. The IPW-RA is a doubly robust estimator that is often extended to estimate multi-valued treatment effects (Cattaneo, 2010). First, IPW uses weighted means rather than simple unweighted means to disentangle the effects of being a student cadre and other confounders. This is particularly important when we have a small number of student cadres but a larger number of non-student cadres in the sample. Second, the use of IPW-RA can be an efficient estimator in multivalued treatment effects estimation. Given the differences between being a student cadre for different lengths of time, such an estimator can be more efficient in empirical studies. By this approach, if both estimation strategies produce a similar result, we can be more confident in our empirical findings.

\section{Empirical results}

\section{Descriptive statistics of student cadres}

Comparing the two-round survey results displayed in Fig. 3, the share of student cadres in class committees did not change significantly, staying relatively stable at around $30 \%$. The majority of the decline is from cadres at university- and department-level SG entities (from 28 to about 7\%). This decline is in accordance with our expectations. As explained above, promotion-style elections within the university and department-level student unions and CYLCs are only open to internal members, with limited positions. Thus, if a senior student cadre cannot be promoted, they often leave the unions or CYLCs.

In Fig. 4, we further present the distribution of student cadres after the second-year election. Panels A and B show the distributions of student cadres from the university- or departmentlevel SG entities and the class committee, respectively. More than $50 \%$ of cadres from the university/department SG were no longer cadres in the second-year election. Only 18-19\% of student cadres continued serving in the university/department SG, and 36-37\% of student cadres were elected to the class committee. Regarding student cadres from the class committee, more than $55 \%$ stayed on, while $38 \%$ did not. $^{3}$

\section{Determinants of student cadre election}

Examining the factors associated with student cadre elections, probit estimations with model (1) and (2) show the estimated results with the first- and second-year cadre election in Table 3. First, previous high school cadre experience had a persistent and strong influence on current student cadre status (for both the class committee and the university/department, the coefficients ranged from 0.18 to 0.32 ). Field interviews indicated that the students were grateful for prior experience, which enabled them to communicate with students and university- and department-level administrative staff. From the administrative staff's standpoint, they

\footnotetext{
${ }^{3}$ A small percentage (around $11 \%$ ) of class committee cadres were elected as university or department student cadres. Field interviews indicated that in rare circumstances, student cadres from the class committee could be (s)elected at university or department CYLCs.
} 


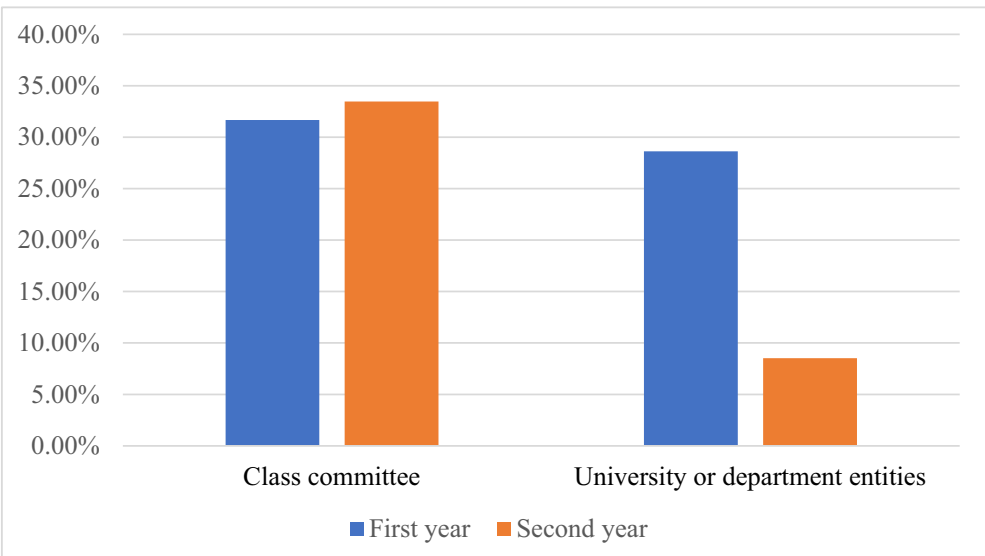

Fig. 3 The change of student cadres in class committee and university or department student government entities. Data source: authors' survey

appreciated working with students with prior experience because these students are often more knowledgeable about administrative challenges, have the ability to coordinate and mobilise students, and are better at reconciling the needs of the students and the university. These experiences are difficult to teach, and are crucial in maintaining the operation of SG.

Second, incumbents had a substantial advantage in winning the second-year election at both the class committee and university/department level. Students who were class committee cadres in the first year had a higher probability of being elected to the class committee in the second year by 0.78 percentage points; prior experience as a university/department student cadre increased the probability of being elected by 0.84 percentage points (rows 2 and 3, columns 3 to 6). Being a class committee cadre could even increase the probability of being elected to university/department SG organisations. However, this did not apply to university/ department cadres with regard to election to the class committee. We did not observe a significant positive (or negative) correlation if students were affiliated to both the class committee and the university/department SG entities. This might partly be because few students were simultaneously affiliated to both types of SG.

Third, we found that CEE score had no effect on the student cadre election (Table 3, row 6); however, the first-year GPA shows a significant positive correlation with being a cadre after the second-year election (both class committee and university/department). This indicates that while students' academic performance does affect their probability of becoming a student cadre, the effect of CEE scores is limited. After university enrolment, CEE scores are no longer relevant, whereas the GPA is of great importance. GPA is not only indicative of academic performance but also reflects the ability to balance academics and the management of student affairs.

\section{Student cadres and their political trust and party membership}

The empirical results show that being a student cadre had rather heterogeneous positive correlations with their political trust. First, we found no correlation between being a student cadre for only one year (university/department or class committee) and their political trust (Table 3, rows 1 and 3). The estimated coefficients were rather small and lacked statistical 


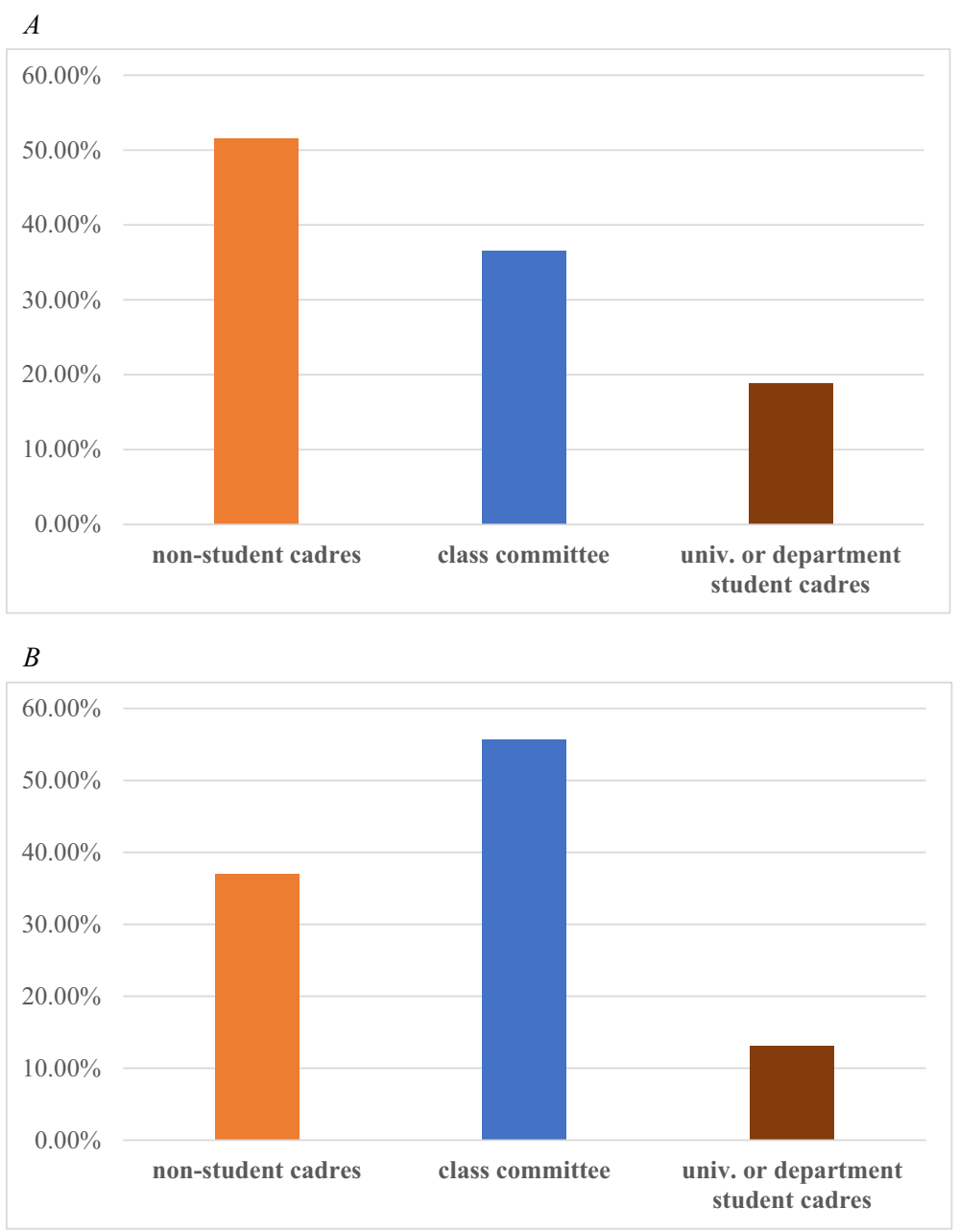

Fig. 4 The distribution of student cadres in the second academic year. Panel $\boldsymbol{A}$ The distribution of university or department cadres after the first academic year Panel $\boldsymbol{B}$ The distribution of class committee cadres after the first academic year. Data source: authors' survey

significance. However, students who had been cadres for two consecutive years showed a significantly higher level of political trust than non-cadres (Table 3, rows 2 and 4). These results were significant at even a $1 \%$ significance level, even though being a student cadre in class committees had a limited positive correlation with their political trust. In Fig. 5, we further present the distributions of political trust. The graphic result shows the same result.

Second, we noticed a significant positive correlation between being a student cadre and students' CCP party membership. Students who had been cadres for two consecutive years had a significantly higher chance of being a CCP member (Table 3, rows 8 and 10). The probit model estimation yielded quite a large coefficient, with persistently significant results. This result also supports our field observation that during college, many student cadres apply to be CCP members, and that gaining this membership could bring student cadres closer to the university and department party-system and administrative offices. 
Table 3 Determinants in being a student cadre, probit model

Is she/he a 1 st year stu- Is she/he a 2 nd year student cadre, $1=y e s$ dent cadre, $1=$ yes

\begin{tabular}{|c|c|c|c|c|}
\hline \multirow{2}{*}{$\begin{array}{l}\text { Class } \\
\text { committee } \\
\text { (1) }\end{array}$} & \multirow{2}{*}{$\begin{array}{l}\text { Univ.- and } \\
\text { depart } \\
\text { (2) }\end{array}$} & \multicolumn{2}{|c|}{ Class committee } & Univ.- and depart \\
\hline & & (3) & (4) & (6) \\
\hline
\end{tabular}

Independent variables

1. A student cadre during high school, $1=$ yes 1 .

$\begin{array}{ll}0.27 * * * & 0.18 * * * \\ (0.06) & (0.05)\end{array}$

2. A class committee cadre during the $1 \mathrm{st}$ year study, $1=$ yes 1 .

3. A univ. or depart cadre during the 1st year study, 1=yes 1 .

4. A cadre at both class and univ./depart entities, $1=y e s 1$.

5. Students' 1st year GPA scores, normalised

6. Students' CEE scores, normalised

-0.00
$(0.00)$

Students' psychological constructs

7. Students' self-reported leadership skills 1.

$0.26^{* * * *}$
$(0.01)$

8. Students' self-reported study strategy1.

9. Students' measured self-efficacyl.

0.06

(0.03)

$-0.04$

(0.02)

0.05

(0.04)

$0.05 * * *$

(0.02)

Yes

11. Students' measured environment adaptation

Students' individual and family characteristics

University and faculty dummies controlled

Constant

Yes

0.14

(0.45)

Observations

Pseudo R-square

2557

0.06

\begin{tabular}{|c|c|c|c|}
\hline $0.28 * * *$ & $0.28 * * *$ & $0.32 * * * *$ & $0.31 * * *$ \\
\hline (0.05) & $(0.05)$ & $(0.07)$ & $(0.07)$ \\
\hline $0.78 * * *$ & $0.76^{* * * *}$ & $0.31 * * *$ & $0.44 * * *$ \\
\hline (0.15) & $(0.14)$ & $(0.09)$ & $(0.17)$ \\
\hline 0.03 & 0.00 & $0.84 * * *$ & $0.95 * * *$ \\
\hline (0.05) & $(0.06)$ & $(0.07)$ & $(0.15)$ \\
\hline & 0.07 & & -0.26 \\
\hline & $(0.06)$ & & $(0.21)$ \\
\hline $0.12 * * *$ & $0.12 * * *$ & $0.07 * *$ & $0.06^{* *}$ \\
\hline (0.04) & $(0.04)$ & $(0.03)$ & $(0.03)$ \\
\hline-0.00 & -0.00 & -0.00 & -0.00 \\
\hline$(0.00)$ & $(0.00)$ & $(0.00)$ & $(0.00)$ \\
\hline $0.07 * * *$ & $0.07 * * *$ & 0.03 & 0.02 \\
\hline (0.02) & $(0.02)$ & $(0.04)$ & $(0.04)$ \\
\hline $0.08 * * *$ & $0.08 * * *$ & $0.07 *$ & $0.07 *$ \\
\hline$(0.03)$ & $(0.03)$ & $(0.04)$ & $(0.04)$ \\
\hline-0.02 & -0.02 & $-0.10 * *$ & $-0.10 * *$ \\
\hline (0.03) & $(0.03)$ & $(0.04)$ & $(0.04)$ \\
\hline-0.04 & -0.04 & $0.06^{* *}$ & $0.06 * *$ \\
\hline (0.03) & $(0.03)$ & $(0.03)$ & $(0.03)$ \\
\hline-0.03 & -0.03 & $0.07 * *$ & $0.07 * *$ \\
\hline (0.04) & $(0.04)$ & $(0.03)$ & $(0.03)$ \\
\hline Yes & Yes & Yes & Yes \\
\hline Yes & Yes & Yes & Yes \\
\hline-0.15 & -0.15 & $-2.71 * * *$ & $-2.79 * * *$ \\
\hline (0.36) & $(0.36)$ & $(0.91)$ & $(0.97)$ \\
\hline 2557 & 2557 & 2557 & 2557 \\
\hline 0.11 & 0.11 & 0.15 & 0.16 \\
\hline
\end{tabular}

Note: (a) In column (2), (3) (5), and (6), we have further controlled students' individual, parents, and family baseline characteristics. For the full list of control variables from the baseline survey was presented in the Online supplementary appendix. (b) Standard errors for inference could be cluster at either university-level (with 22 cluster for the first analysis, and 7 clusters for the second analysis), or at department-level (with 62 clusters for the second analysis). We reported the university level clustered-robust standard errors in parentheses, ${ }^{* * *} \mathrm{p}<0.01,{ }^{* *}$ $\mathrm{p}<0.05,{ }^{*} \mathrm{p}<0.1$; however, the results hold if we clustered the standard errors in department-level

Data source: author's survey

\section{Discussion and conclusion}

It is well acknowledged that student involvement can be an essential component in promoting the quality of HE governance (Obondo, 2000; Luescher, 2013). When policymakers consider the internal governance of HE, understanding how students should and could be involved is imperative. However, questions such as how SG is structured and operated, to what extent a SG is autonomous, and how these SG entities represent the interests of college students have seldom been discussed in vast developing countries. 
Table 4 Bing a cadre and students' political trust and party membership

Outcome 1: Measured students' political trust at the end of second academic year

Ordinary least IPW-RA $\dagger$ Ordinary least IPW-RA $\dagger$ square square
(1)
(2)
(3)
(4)

\begin{tabular}{|c|c|c|c|c|}
\hline \multicolumn{5}{|l|}{ Treatment variables } \\
\hline \multirow{2}{*}{$\begin{array}{l}\text { 1. Student cadre at univ. or department entities for } \\
\text { ONE year, } 1=\text { yes } 1 \text {. }\end{array}$} & -0.03 & 0.01 & & \\
\hline & $(0.06)$ & $(0.05)$ & & \\
\hline \multirow{2}{*}{$\begin{array}{l}\text { 2. Student cadre at univ. or department entities for } \\
\text { TWO years, } 1=\text { yes } 1 \text {. }\end{array}$} & $0.21 * * *$ & $0.28 * * *$ & & \\
\hline & $(0.06)$ & $(0.09)$ & & \\
\hline \multirow{2}{*}{$\begin{array}{l}\text { 3. Student cadre at the class committee for } \underline{\mathbf{O N E}} \\
\text { year, } 1=\text { yes } 1 \text {. }\end{array}$} & & & 0.04 & 0.05 \\
\hline & & & $(0.04)$ & $(0.05)$ \\
\hline \multirow{2}{*}{$\begin{array}{l}\text { 4. Student cadre at the class committee for } \mathbf{T W O} \\
\text { years, } 1=\text { yes } 1 \text {. }\end{array}$} & & & $0.12 *$ & $0.14 * *$ \\
\hline & & & $(0.06)$ & $(0.06)$ \\
\hline \multirow{2}{*}{$\begin{array}{l}\text { 5. Student's personal characteristic controlled } \\
\text { 6. University/department dummies }\end{array}$} & Yes & Yes & Yes & Yes \\
\hline & Yes & Yes & Yes & Yes \\
\hline \multirow[t]{2}{*}{ Constant } & -0.31 & -0.01 & -0.35 & -0.03 \\
\hline & $(0.49)$ & $(0.02)$ & $(0.49)$ & $(0.03)$ \\
\hline R-squared & 0.08 & - & 0.08 & - \\
\hline No. of observations & 2557 & 2557 & 2557 & 2557 \\
\hline \multirow[t]{3}{*}{ No. of clusters } & 62 & 62 & 62 & 62 \\
\hline & $\begin{array}{l}\text { Outcome 2: If } \\
\text { of second a }\end{array}$ & $\begin{array}{l}\text { udent becor } \\
\text { demic year, }\end{array}$ & $\begin{array}{l}\text { ne CCP memb } \\
1=\text { yes }\end{array}$ & by the end \\
\hline & Probit model & IPW-RA & Probit model & IPW-RA $\dagger$ \\
\hline \multicolumn{5}{|l|}{ Treatment variables } \\
\hline \multirow{2}{*}{$\begin{array}{l}\text { 7. Student cadre at univ. or department entities for } \\
\text { ONE year, } 1=\text { yes } 1 \text {. }\end{array}$} & $0.31 * * *$ & $0.03 * * *$ & & \\
\hline & $(0.11)$ & $(0.01)$ & & \\
\hline \multirow{2}{*}{$\begin{array}{l}\text { 8. Student cadre at univ. or department entities for } \\
\text { TWO years, } 1=\text { yes } 1 \text {. }\end{array}$} & $0.95 * * *$ & $0.13 * * *$ & & \\
\hline & $(0.15)$ & $(0.02)$ & & \\
\hline \multirow{2}{*}{$\begin{array}{l}\text { 9. Student cadre at the class committee for } \mathbf{O N E} \\
\text { year, } 1=\text { yes } 1 \text {. }\end{array}$} & & & $0.55 * * *$ & $0.04 * * *$ \\
\hline & & & $(0.12)$ & $(0.01)$ \\
\hline \multirow{2}{*}{$\begin{array}{l}\text { 10. Student cadre at the class committee for TWO } \\
\text { years, } 1=\text { yes }\end{array}$} & & & $0.74 * * *$ & $0.06^{* * *}$ \\
\hline & & & $(0.12)$ & $(0.01)$ \\
\hline \multirow{2}{*}{$\begin{array}{l}\text { 11. Student's personal characteristic controlled } \\
\text { 12. University/department dummies }\end{array}$} & Yes & Yes & Yes & Yes \\
\hline & Yes & Yes & Yes & Yes \\
\hline \multirow[t]{2}{*}{ Constant } & $-8.83 * * *$ & 0.04 & $-8.93 * * *$ & 0.03 \\
\hline & $(1.57)$ & $(0.01)$ & $(1.48)$ & $(0.01)$ \\
\hline R-squared & 0.20 & - & 0.21 & - \\
\hline No. of observations & 2557 & 2557 & 2557 & 2557 \\
\hline No. of clusters & 62 & 62 & 62 & 62 \\
\hline
\end{tabular}

Note: $\dagger$ indicates the analysis with the inverse-probability weighted model with linear regression adjusted; and $\ddagger$ indicates the analysis with the inverse-probability weighted model with the probit regression adjustment. Robust standard errors in parentheses, $* * * \mathrm{p}<0.01, * * \mathrm{p}<0.05, * \mathrm{p}<0.1$

Data source: author's survey

We studied SG in China's HE by using both qualitative cases and quantitative statistics. Our qualitative investigation found that the distribution of power in SGs is skewed towards CCP-affiliated bodies, such as CYLCs and CPCs, significantly undermining the autonomy of student unions. We also found that class committee-level elections somehow exhibit a higher degree of autonomy and better student representation than university/department-level student unions and CYLCs, not least because universities' CYLCs are directly influenced by CPCs. Our quantitative investigation found that students' previous experience had a strong effect on the likelihood of being elected to SG positions. This previous experience also gave incumbents 
A

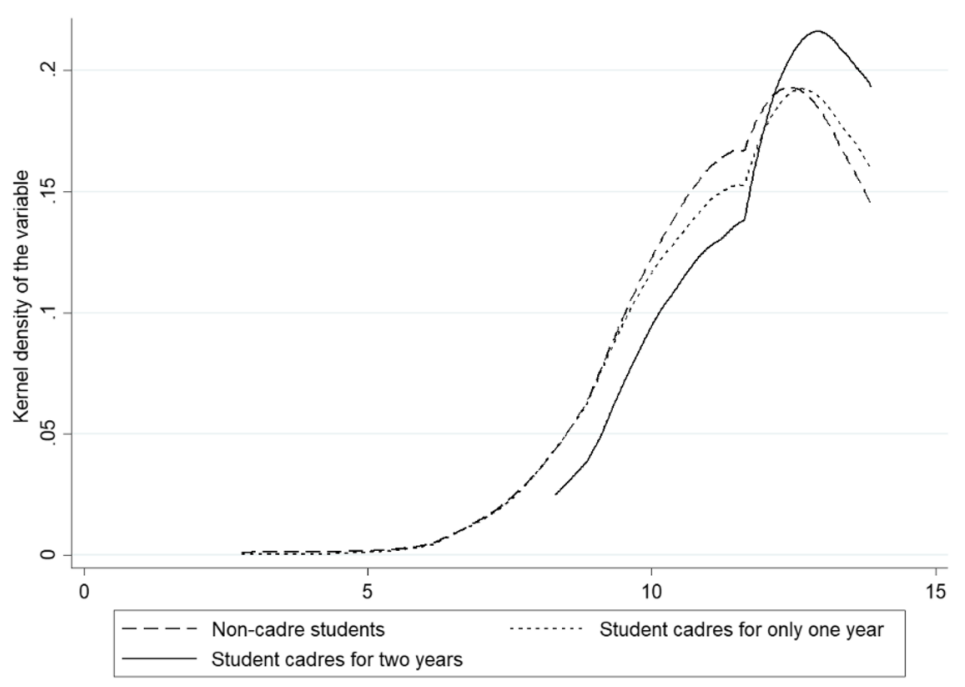

B

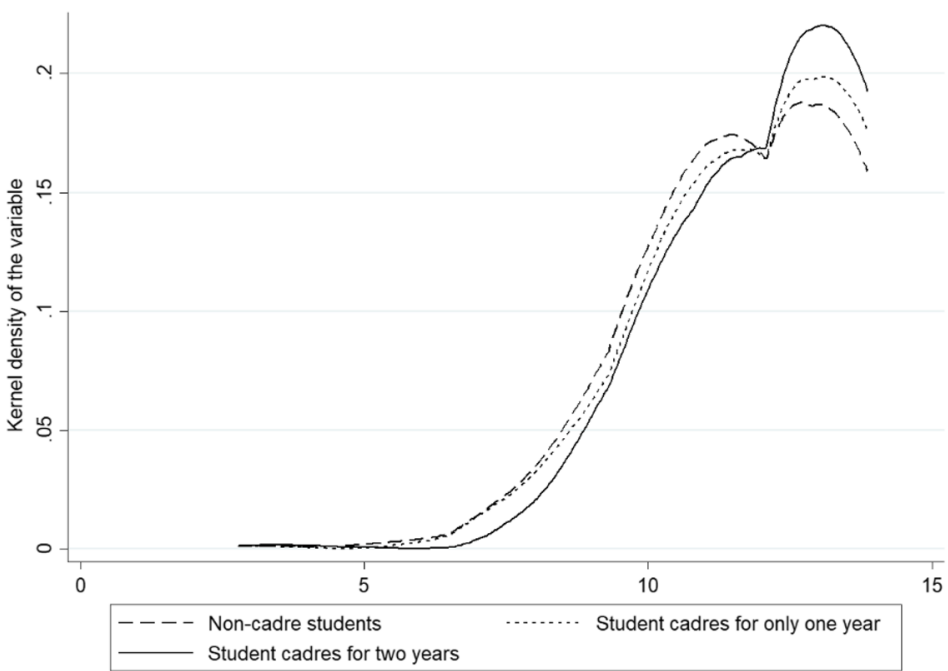

Fig. 5 The distribution of student' political trust. Panel A Non-cadre students and cadres from university or department entities. Panel B Non-cadre students and cadres from the class committees. Data source: authors' survey

an advantage in continuing to serve as student cadres. Academic performance and leadership efficacy played important roles in student cadre election. Good academic performance and high levels of leadership efficacy reflected the capability and confidence to be a student cadre. Moreover, while being a student cadre for one year did not necessarily increase political trust, student cadres who could be re-elected showed a significantly higher level of political trust. Furthermore, being a student cadre greatly increased their probability of becoming a CCP 
member, which again reflects the dominant position of CCP-affiliated entities in SG in China's HE governance.

In sum, there are several distinguished phenomena in China's HE student government, which requires special attention. First, despite the trend towards decentralisation in HE governance (Green, 2007), centralisation remains dominant in the Chinese context (Hawkins, 2000). Through the leading role of CCP and CYLCs in SG, university administrators could extend their control over important decision-making at the macro level. At the micro level, class committees enjoyed certain degrees of decentralisation, enabling flexibility in student involvement in governance. Such an internal governance style might exhibit certain advantages, including effective governing, forming consensus, and ensuring certain autonomy; however, the dominance of CCP and the corresponding CYLCs over student unions and numerous class committees might inhibit effective student participation in decision-making in HE governance, ultimately limiting the potential of HE development. Second, student cadres in China's HE are institutionally recognised as elites, who have the skills and experiences to reconcile and coordinate the interests of different stakeholders, particularly students and CYLCs. Such elitism might be partially attributed to the drastic massification of HE in China since 2000 (Mok \& Han, 2017; Mok, 2016). The fast expansion of HE enrolment with the fear of loss of control demands internal governance with an increasing level of student elitism; student elites are integrated into the wide party-affiliated system, while non-elites are unable to survive in such a competitive environment. This might also explain why we did not observe a significant increase in political trust among students who had only been cadres for one school year. Third, effective student involvement in HE governance will be increasingly stressed (Li \& Zhao, 2020; Luescher, 2020; Tu, 2011). This is not only owing to an increasing level of globalisation in HE, but also because with China's continuous economic development and individual economic growth, there will be more demands for participation in decision-making from college students (Li \& Zhao, 2020; Serger et al., 2015). In such a situation, the current SG structure and operation with its skewed power distribution and limited student representation would no longer be acceptable. Thus, determining the policies for student involvement in HE governance to be designed and identifying how HE governance should be reformed will be crucial. However, examining the current 'Double First-Class University Plan', we noticed that there is limited scope for reform of internal governance (such as SG) where students' involvement in decision-making can be increased, but much attention has been placed on university ranking and financial distributions.

Nevertheless, when making comparisons with studies from both within and outside China, we should be careful in extending our findings. First, our findings are consistent with some early studies regarding China's HE governance; however, the strong party-leading model of Chinese HE is far different from the global decentralising HE governance trend (Daun \& Mundy, 2011). For instance, Wang (2010) concluded that the coexistence of dual controlling mechanisms (the CCP and the university administrative system) and neo-liberal practices showed an innovative scope of the state capacity in China's HE, which hardly can be observed in other developing countries. Second, current studies on Chinese HE governance are mainly descriptive and case studies, which could serve a great exploratory purpose (Li \& Zhao, 2020; Wang, 2010); however, limited comparisons (both through time and across country comparisons) can be conducted. More quantitative evidence should be provided with large-scale field data; thus, theories could be tested, and the development paths can be observed. Third, both Chinese and international HE governance are experiencing dynamic changes (Huang et al., 2018). With continuous massification, there is an increasing trend towards a neoliberal 
managerial model of governance both in China and globally (Lynch \& Grummell, 2018). Given the drastic historical differences in HE governance and the increasing complexity of $\mathrm{HE}$ sectors resulting from globalisation to what extent our findings pertaining to China are generalisable can only be determined through more rigorous comparative examinations.

In summary, however, we argue that it is important to examine the current design and operation of SGs in contemporary Chinese HE. Scholars should pay special attention to the representativeness and autonomy of SGs in Chinese HE and investigate the potential effects of SG membership on students' development. Most contemporary studies on Chinese HE focusses on the accumulation of human capital; however, our study and several others suggest that $\mathrm{HE}$ is not merely about training a qualified labour force but also cultivating qualified citizens. It is essential for high-quality HE to have high-quality internal governance, and more rigorous studies should be conducted in this regard in the Chinese context.

Supplementary Information The online version contains supplementary material available at https://oi.org/ 10.1007/s10734-021-00721-8.

Funding Information We thank the China National Social Science Foundation for financial support (grant number: 19VSZ118).

Open Access This article is licensed under a Creative Commons Attribution 4.0 International License, which permits use, sharing, adaptation, distribution and reproduction in any medium or format, as long as you give appropriate credit to the original author(s) and the source, provide a link to the Creative Commons licence, and indicate if changes were made. The images or other third party material in this article are included in the article's Creative Commons licence, unless indicated otherwise in a credit line to the material. If material is not included in the article's Creative Commons licence and your intended use is not permitted by statutory regulation or exceeds the permitted use, you will need to obtain permission directly from the copyright holder. To view a copy of this licence, visit http://creativecommons.org/licenses/by/4.0/.

\section{References}

Akomolafe, C., \& Ibijola, E. Y. (2011). Students' participation in university governance and organizational effectiveness in Ekiti and Ondo States, Nigeria. American Journal of Social and Management Sciences, 2(2), 231-236.

Altbach, P. G. (1984). Student politics in the Third World. Higher Education, 13(6), 635-655.

Altbach, P. (2009). One-third of the globe: The future of higher education in China and India. Prospects, 39, 1131.

Anderson, C., \& Galinsky, A. D. (2006). Power, optimism, and risk-taking. European Journal of Social Psychology, 36(4), 511-536.

Beaman, L., Duflo, E., Pande, R., \& Topalova, P. (2012). Female leadership raises aspirations and educational attainment for girls: A policy experiment in India. Science, 335(6068), 582-586.

Bertrand, M., \& Schoar, A. (2003). Managing with style: The effect of managers on firm policies. Quarterly Journal of Economics, 118(4), 1169-1208.

Boland, J. (2005). Student participation in shared governance: A means of advancing democratic values? Tertiary Education and Management, 11, 199-217.

Cattaneo, M. D. (2010). Efficient semiparametric estimation of multi-valued treatment effects under ignobility. Journal of Econometrics, 155, 138-154.

Chattopadhyay, R., \& Duflo, E. (2004). Women as policy makers: Evidence from a randomized policy experiment in India. Econometrica, 72(5), 1409-1443.

Christopher, J. (2012). Governance paradigms of public universities: An international comparative study. Tertiary Education and Management, 18(4), 335-351.

Currie, J., DeAngelis, R., de Boer, H., Huisman, J., \& Lacotte, C. (2003). Globalization practices and university responses: European and Anglo-American differences. Praeger. 
Daun, H., \& Mundy, K. (2011). Educational governance and participation: With focus on developing countries. Institute of International Education Report 120.

Day, M. (2012). Dubious causes of no interest to students? The development of National Union of Students in the United Kingdom. European Journal of Higher Education, 2(1), 32-46.

Deng, W., Li, X., Wu, H., \& Xu, G. (2020). Student leadership and academic performance. China Economic Review, 101389.

Dill, D. (2007). Quality assurance in higher education: Practices and issues. In B. McGraw, E. Baker, \& P. Peterson (Eds.), International encyclopedia of education (3rd ed., pp). Elsevier Publications.

Downey, R. G., Bosco, P. J., \& Silver, E. M. (1984). Long-term outcomes of participation in student government. Journal of College Student Personnel, 25(3), 245-250.

Elliot, A. (1999). Approach and avoidance motivation and achievement goals. Educational Psychologist, 34, $169-189$.

Elliot, A., \& Church, M. (1997). A hierarchical model of approach and avoidance achievement motivation. Journal of Personality and Social Psychology, 72, 218-232.

Fang, W., \& Wang, M. (2018). Empirical research of factors influencing college students' political trust: Analysis of university-related factors and the current situation. Journal of Shanghai Jiaotong University (Philosophy and Social Sciences), 26(1), 53-62.

Galinsky, A. D., Gruenfeld, D. H., \& Magee, J. C. (2003). From power to action. Journal of Personality and Social Psychology, 85(3), 453-466.

Galinsky, A. D., Magee, J. C., Inesi, M. E., \& Gruenfeld, D. H. (2006). Power and perspectives not taken. Psychological Science, 17(12), 1068-1074.

Giannakis, M., \& Bullivant, N. (2016). The massification of higher education in the UK: Aspects of service quality. Journal of Further and Higher Education, 40(5), 630-648.

Green, A. (2007). Globalisation and the changing nature of the state in East Asia. Globalisation, Societies and Education, 5(1), 23-38.

Grove, J., (2017). China targets "world-class" status for 42 universities. Times Higher Education. Retrieved September 20, 2019, from https:/www.timeshighereducation.com/news/china-targets-world-class-status-42universities

Hawkins, J. (2000). Centralization, decentralization, recentralization: Educational reform in China. Journal of Educational Administration, 38(5), 442-454.

Hirsch, W. Z. (2001). Initiatives for improving shared governance. In W. Z. Hirsch \& L. E. Weber (Eds.), Governance in higher education: The university in a state of flux (p. 204). Economica.

Hornsby, D., \& Osman, R. (2014). Massification in higher education: Large classes and student learning. Higher Education, 67(6), 11-719.

Houwing, J. F., \& Kristjanson, A. M. (1975). Composition of governing bodies of Canadian universities and colleges. Association of Universities and College of Canada.

Huang, F. (2006). Incorporation and university governance: A comparative perspective from China and Japan. Higher Education Management and Policy, 18(2), 35-49.

Huang, Y., Pang, S., \& Yu, S. (2018). Academic identities and university faculty responses to new managerialist reforms: Experiences from China. Studies in Higher Education, 43(1), 154-172.

Hunan Department of Education (2017). Hunan education statistic yearbook (2016). Retrieved September 20, 2019, from http://jyt.hunan.gov.cn/sjyt/xxgk/ghjh/tjxx/201703/t20170331_4322803.html (in Chinese).

Imbens, G. W. (2000). The role of the propensity score in estimating dose-response function. Biometrika, 87(3), 706-710.

Jessup-Anger, E. (2020). Student government. In M. David \& M. Amey (Eds.), The SAGE Encyclopaedia of Higher Education (Vol. 1, pp. 1436-1437). SAGE Publications Inc.

Johnstone, B. (2003). Cost sharing in higher education: Tuition, financial assistance, and accessibility in a comparative perspective. Czech Sociological Review, 39(3), 351-374.

Jones, B. F., \& Olken, B. A. (2005). Do leaders matter? National leadership and growth since World War II. Quarterly Journal of Economics, 120(3), 835-864.

Jones, G. A., \& Skolnik, M. L. (1997). Governing boards in Canadian universities. The Review of Higher Education, 20(3), 277-295.

Klemenčič, M. (2012). Student representation in Western Europe: Introduction to the special issue. European Journal of Higher Education, 2(1), 2-19.

Klemenčič, M. (2014). Student power in a global perspective and contemporary trends in student organising. Studies in Higher Education, 39(3), 396-411.

Klemenčič, M., Bergan, S., \& Primožič, R. (Eds.). (2015). Student engagement in Europe: Society, higher education and student governance (Council of Europe Higher Education Series No. 20). Council of Europe Publishing. 
Komives, S. R., \& Johnson, M. (2009). The role of high school experience in college student leadership development. Educational Considerations, 37(1), 30-39.

Kuh, G., \& Lund, J. (1994). What students gain from participating in student government. In M. Terrell \& M. Cuyjet (Eds.), New directions for student services (pp. 5-17). Jossey-Bass.

Kuruuzum, A., Asilkan, O., \& Cizel, B. (2005). Student participation in higher education institutions in Turkey. Higher Education in Europe, 30(3-4), 345-355.

Li, X., \& Zhao, G. (2020). Democratic involvement in higher education: A study of Chinese student eparticipation in university governance. Higher Education Policy, 33, 65-87.

Liu, Q., Turner, D., \& Jing, X. (2019). The "double first-class initiative” in China: Background, implementation, and potential problems. Beijing International Review of Education, 1(1), 92-108.

Luescher, T. M. (2013). Student representation in university decision making: Good reasons, a new lens? Studies in Higher Education, 38(10), 1442-1456.

Luescher, T. M. (2020). Student governance. In M. David \& M. Amey (Eds.), The SAGE Encyclopaedia of Higher Education, 1 (pp. 1434-1435). SAGE Publications, Inc.

Luescher, T. M., \& Klemenčič, M. (2016). Student power in twenty-first century Africa: The character and role of student organising. In R. Brooks (Ed.), Student politics and protests (pp. 1-21). Surrey University.

Lundin, M., Skans, O. N., \& Zetterberg, P. (2019). Leadership experiences, labor market entry, and early career trajectories. Journal of Human Resources, 0617-8866R3.

Lynch, K., \& Grummell, B. (2018). New managerialism as an organisational form of neoliberalism. In F. Sowa, R. Staples, \& S. Zapfel (Eds.), The transformation of work in welfare state organizations: New public management and the institutional diffusion of ideas. Routledge.

Malmendier, U., \& Tate, G. (2005). CEO overconfidence and corporate investment. The Journal of Finance, 60(6), 2661-2700.

Marginson, S., \& Considine, M. (2000). The enterprise university: Power, governance and reinvention in Australia. Cambridge University Press.

May, W. (2010). The history of student governance in higher education. College Student Affairs, 28(2), $207-220$.

McFarland, D., \& Starmanns, C. E. (2009). Inside student government: The variable quality of high school student councils. Teachers College Record, 111(1), 27-54.

Menon, M. (2005). Students' views regarding their participation in university governance: Implications for distributed leadership in higher education. Tertiary Education and Management, 11, 167-182.

Midgley, C., Maehr, M. L., Hruda, L. Z., Anderman, E. M., Anderman, L., Freeman, K. E., \& Urdan, T. (2000). Manual for the patterns of adaptive learning scales. The University of Michigan.

Mok, K. H. (2016). Massification of higher education, graduate employment and social mobility in the Greater China region. British Journal of Sociology of Education, 37(1), 51-71.

Mok, K. H., \& Han, X. (2017). Higher education governance and policy in China: Managing decentralization and transnationalism. Policy and Society, 36(1), $34-48$.

Neubauer, D., \& Gomes, C. (2017). Quality assurance in Asia-Pacific universities: Implementing massification in higher education. Palgrave Macmillan.

Ngok, K. (2008). Massification, bureaucratization and questing for "word-class" status higher education in China since the mid-1990s. International Journal of Educational Management, 22(6), 547-564.

Obondo, A. T. (2000). Politics of participatory decision-making: The case of Kenyatta University of Nairobi, Review No. 19. French Institute for Research in Africa.

Parejo, J. L., \& Lorente, J. (2012). From student associations to CEUNE: The development of student representation in Spain. European Journal of Higher Education, 2(1), 78-94.

Pascarella, E. T., \& Terenzini, P. T. (1991). How college affects students: Findings and insights from twenty years of research. Jossey-Bass.

Peters, M. A., \& Besley, T. (2018). China’s double first-class university strategy: 双一流. Educational Philosophy and Theory, 50(12), 1075-1079.

Rytmeister, C. (2009). Governing university strategy: Perceptions and practice of governance and management roles. Tertiary Education and Management, 15(2), 137-156.

Serger, S., Benner, M., \& Li, L. (2015). Chinese university governance: Tensions and reforms. Science and Public Policy, 42, 871-886.

Stensaker, B., \& Michelsen, S. (2012). Governmental steering, reform and the institutionalization of student interest in higher education in Norway. European Journal of Higher Education, 2(1), 20-31.

Tu, Y. (2011). Citizenship with Chinese characteristics? An investigation into Chinese university students' civic perceptions and civic participation. Frontiers of Education in China, 6(3), 426-448. 
Vidovich, L., \& Currie, J. (2011). Governance and trust in higher education. Studies in Higher Education, 36(1), 43-56.

Wang, L. (2010). Higher education governance and university autonomy in China. Globalization, Societies and Education, 8(4), 477-495.

Yang, D. P. (2005). The new development paradigm and China's education. In X. Ru, X. Lu, P. Li, P. Huang, \& G. Chen (Eds.), Analysis and forecast of the Chinese social situation. Social Sciences Literature Press.

Publisher's note Springer Nature remains neutral with regard to jurisdictional claims in published maps and institutional affiliations.

\section{Affiliations}

\section{Wei Huang ${ }^{1} \cdot$ Panpan $\mathrm{Yao}^{1} \cdot \mathrm{Fan}_{\mathrm{Li}^{2}} \cdot \mathrm{Xiaowei}_{\mathrm{Liao}}{ }^{1}$}

1 School of Economics and Management, Changsha University of Science and Technology, Changsha, China

2 Development Economics Group, Wageningen University and Research, Wageningen, the Netherlands 